\title{
ANALISIS PENERAPAN PENGENDALIAN INTERN PADA PERSEDIAAN BARANG DAGANGAN UNTUK MENINGKATKAN EFEKTIVITAS MANAJEMEN PERSEDIAAN (Studi Kasus PT.Satria Karya Adi Yudha,Tbk di Sidoarjo )
}

\author{
*Safitri Damayanti, Tri Lestari, Siti Rosyafah \\ Fakultas Ekonomi dan Bisnis Universitas Bhayangkara Surabaya, Indonesia
}

DOI: 10.46821/ekobis.v1i1.10

\begin{abstract}
ABSTRAK
Persediaan adalah salah satu aktiva penting yang dimiliki oleh perusahaan, sehingga harus dilakukan sistem dan prosedur pengeluaran barang yang memadai dalam kelancaran proses pengiriman barang. Oleh karena itu, tujuan dari penelitian ini adalah menganalisis dan mengevaluasi perancangan dan penerapan sistem informasi akuntansi persediaan yang terdapat pada perusahaan. Lokasi kajian dalam penelitian ini adalah Gudang Distributor PT.Satria Karya AdiYudha Sidoarjo. Untuk memperoleh data yang diperlukan maka penulis menggunakan metode pengumpulan data berupa wawancara, observasi dan kepustakaan sedangkan metode analisis yang digunakan adalah metode deskriptif kualitatif. Dalam penelitian ini, jenis data yang digunakan adalah data primer dan sekunder. Dari hasil penelitian dapat disimpulkan bahwa peranan sistem informasi akuntansi persediaan barang dagang dalam kelancaran pendistribusian pada gudang distributor PT. Satria Karya AdiYudha Sidoarjo.masih kurang memadai sehingga penulis memberikan usulan sistem informasi akuntansi yang sesuai dengan prosedur pengeluaran barang dagang yang memadai agar sistem informasi akuntansi persediaan pada gudang distributor PT. Satria Karya Adi Yudha.
\end{abstract}

\begin{abstract}
Inventory is one of the important assets owned by the company, so it should be systems and procedures were adequate expenditures in the smooth delivery of goods. Therefore, the purpose of this study was to analyze and evaluate the design and implementation of information systems inventory accounting contained in the company. Location study in this research is the Warehouse Distributor PT. Satria Karya Adi Yudha Sidoarjo. To obtain the necessary data, the authors use data collection methods such as interviews, observation and literature while the method of analysis used is descriptive qualitative method. In this study, the type of data used is primary and secondary data. From the results of this study concluded that the role of accounting information system merchandise inventory in the smooth distribution of the warehouse distributor PT. Satria Karya Adi Yudha Sidoarjo is still inadequate so the authors propose that the accounting information system in accordance with the procedure expenditure so that sufficient merchandise inventory accounting information system at the warehouse distributor PT. Satria Karya Adi Yudha Sidoarjo can be better.
\end{abstract}




\section{PENDAHULUAN}

Secara umum ,perusahaan barang dagang dapat didefinisikan sebagai organisasi yang melakukan kegiatan usaha dengan membeli barang dari pihak/perusahaan lain kemudian menjualnya kembali kepada masyarakat. setiap perusahaan pasti bertujuan untuk menghasilkan laba yang optimal agar dapat mempertahankan kelangsungan hidupnya, memajukan usahanya serta mengembangkan usahanya ketingkat yang lebih tinggi. Dengan berkembang pesatnya dunia usaha saat ini khususnya pada perusahaan di Indonesia. Dengan adanya persaingan yang cukup sulit dalam perusahaan perdagangaan maupun perindustrian .

Dalam persaingan yang semakin sulit ini mengharuskan agar perusahaan dalam mengelolah semua sumber daya yang perusahaan miliki, seoptimal mungkin agar perusahaan mampu menghasilkan serta menawarkan atau mempromosikan suatu produk yang sedang diinginkan oleh konsumen dengan kualitasnya yang bagus dan harga yang terjangkau yang masyarakat mampu untuk memilikinya.

Oleh karena itu Persediaan barang dagangan mempunyai peran yang sangat penting dalam menunjang kelangsungan berkembangan atau kehidupan perusahaan dagang, karena perusahaan dagang ini merupakan suatu asset yang terbesar dibandingkan neraca yang lain. Untuk pengelolahan suatu persediaan ini dapat melakukan penanganan persediaan secara wajar dimulai dari pengadaannya, penyimpanannya, sampai dengan proses pengeluarannya. Persediaan ini harus selalu ada karena sangat diperlukan, dengan kuantitas maupunkualitas yang sangat memadai. Jika dalam suatu perusahaan ada kelalaian dalam persediaan akan memberikan nilai yang negatif bagi perusahaan. Melihat perkembangan pasar yang semakin berkembang dan keinginan perusahan untuk lebih meningkat, Serta lemahnya suatu pengendaliaan akan menimbulkan penyalagunaan wewenang serta penyelewengan maka perusahaan akan mengalami suatu kerugian yang terjadi akibat penyimpangan serta kelalaian

tersebut, Maka dari itu dalam suatu perusahaan diperlukan suatu pengendalian internal yang memadai dalam melaksakan persediaan barang dagangan untuk pasar, pengendalian suatu perusahaan terdiri dari kebijakan kebijakan yang diciptakan memberikan jaminan yang cukup baik serta memadai agar suatu keinginan serta tujuan perusahaan mampu mencapai tujuannya dengan optimal. disini kebijakan ialah pedoman yang dibuat oleh manajemen dalam mencapai tujuan perusahaan, dan prosedur . Prosedur ialah langkah - langkah yang harus dilakukan oleh perusahaan, dan tujuan akhir dari kegiatan yang sesuai dengan sasaran yang dicapai adalah maksimal.

Maka dari adanya Penelitian yang dilakukan Anisa Novita Sari Lukbin (2015 ) dengan judul Analisis Pengendalian Internal Atas Persediaan Barang dagang pada "PT. Wavin Tunas Utama Surabaya".dengan masalah yang dibahas, Apakah pengendalian internal atas persediaan barang degang pada PT .Wavin Tunas Utama Surabaya sudah berjalan dengan efektif, serta penelitian ini bertujuan untuk mendapatkan gambaran yang jelas mengenai penerapan dan pengendalian internal persediaan barang sedang yang diterapkan oleh PT.Wavin Tunas Utama Surabaya . pengendalian internal yang baik serta teratur dalam melakukan proses mengelolah persediaan barang dagangan, maka suatu pimpinan akan memperoleh hasil laporan - laporan yang sangat bermanfaat untuk 
meningkatkan efektifitas perusahaan, serta dapat membantu dalam pengambilan keputusan serta pertanggung -jawaban untuk memimpin suatu perusahaan.

Dari pertimbangan diatas, maka Penulis tertarik untuk mengadakan penelitian.Dengan judul yang dipilih adalah "Analisis Penerapan Pengendalian Intern Pada Persediaan Barang Dagangan Untuk Meningkatkan Efetivitas Manajemen Persediaan Pada PT.Satria Karya Adi Yudha Sidoarjo."

\section{METODE PENELITIAN}

Dalam penyusunan skripsi ini, fokus hanya akan mengacu pada Analisis Penerapan Pengendalian Intern Pada persediaan Barang dagangan untuk meningkatkan efektivitas manajemen persediaan pada PT Satria Karya Adi Yudha sidoarjo. Oleh karena itu metodologi penelitian yang digunakan adalah metodelogi kualitatif, yaitu suatu metode yang menggunakan data berupa kalimat tertulis atau lisan, perilaku, fenomena peristiwa-peristiwa, pengetahuan atau obyek studi yang bertujuan untuk menggambarkan keadaan perusahaan berdasarkan fakta nyata pada situasi yang diselidiki.

Penelitian ini menggunakan metode kualitatif karena metode ini menyajikan secara langsung hakikat hubungan antara peneliti dengan responden, hal ini sesuai dengan penyataan Moloeng (2004:4), bahwa ada beberapa karakteristik dalam pendekatan penelitian, yaitu peneliti harus turut berperan serta pada waktu pengumpulan data sehingga peneliti tidak selamanya berada diluar obyek studi, tetapi sebagai bagian obyek studi.

Selain itu, untuk mewujudkan maksud penelitian ini, penulis juga menggunakan metode study survey yang dilakukan dengan cara sebagai berikut:

a. Penelitian Lapangan (Filed Research)

Metode penelitian ini dilakukan langsung pada objek penelitian, data serta keterangan yang dikumpulkan dilakukan dengan cara:

1. Pengamatan (Observasi)

Dalam hal ini penulis bertindak sebagai rekan kerja yang melakukan pengamatan untuk mendapatkan gambaran perusahaan dan juga data secara umum dengan melihat langsung, mengamati dan mencatat system yang sedang berjalan serta melihat format-format yang dilakukan selama ini.

2. Wawancara (Interview)

Dalam hal ini penulis melakukan wawancara untuk melengkapi bahan yang sudah ada selama observasi.Penulis melakukan Tanya jawab kepada staff yang berkaitan dengan masalh yang sedang diteliti.

b. Penelitian Perpustakaan (Library Research)

Penulis perpustakaan adalah penelitian dengan sumber-sumber perpustakaan. Penelitian ini dimaksudkan untuk mendapatkan landasan teori yang memadai dalam penyusunan tugas akhir ini, dalam hal ini data dan keterangan dikumpulkan dari sumber-sumber yang relevan seperti buku-buku teks, bacaan-bacaan, bahanbahan perkuliahan serta materi-materi lainnya yang berhubungan dengan masalah yang ditinjau dalam penyusunan tugas akhir ini.

Peneliti menggunakan metodi studi kasus karena metode ini sesuai dengan tujuan peneliti yang akan memecahkan masalah perusahaan yang berhubungan dengan kelancaraan proses persediaan barang dagang mengenai mengendalikan barang dagang dengan tepat agar tidak terjadi kekurangan stok barang dagang 
pada PT. Satria Karya Adi Yudha sidoarjo. Studi kasus dilakukan langsung ke obyek peneliti yaitu bagian persediaan dan proses pengadaan barang untuk pengambilan data terhadap obyek yang diteliti.

\section{HASIL ANALISIS DAN PEMBAHASAN}

Berkantor pusat di Jakarta, PT. Satria Karya Adi Yudha sudah dikenal sejak tahun 1990 sebagai perusahaan yang terpercaya dan dapat diandalkan .Dengan jaringan luas yang meliputi pusat distribusi di kota -kota besar di Indonesia , PT. Satria Karya Adi Yudha berkomitmen untuk menghadirkan produk-produk terbaik bagi konsumen secara tepat jumlah dan tepat waktu. Tidak menjadi masalah apakah perusahaan anda adalah korporasi multi nasional ataupun perusahaan dalam negeri yang sedang berkembang.

PT. Satria Karya Adi Yudha selalu siap dan mampu untuk memenuhi kebutuhan anda. Jaringan dan penetrasi pasar PT. Satria Karya Adi Yudha sudah menjangkau lebih dari 9.000 outlet besar dan kecil di seluruh Indonesia; Dengan principal dari seluruh dunia, seperti India, China, Australia, Swiss, dan Jerman. Keahlian logistik kami di PT. Satria Karya Adi Yudha memastikan bahwa produk anda akan terkirim kapan dan dimana pasar membutuhkannya. struktur organisasi yang ada pada gudang distributor PT. Satria Karya Adi Yudha cabang Sidoarjo yaitu:

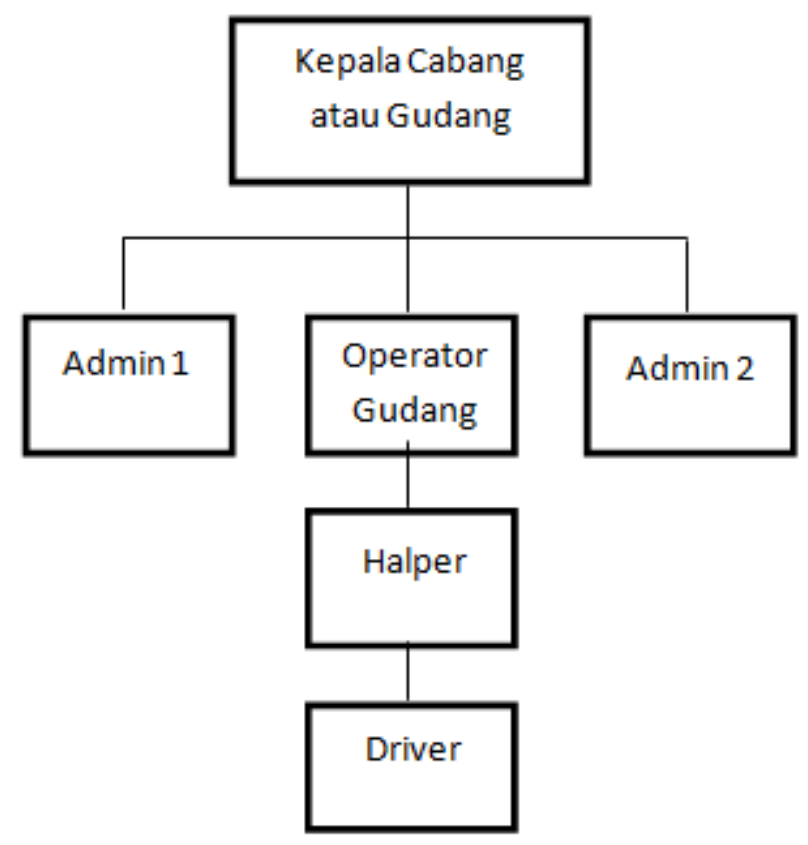

Sumber: Gudang Distributor PT Satria Karya Adi Yudha Sidoarjo, 2018

Gambar 1

Struktur Organisasi Gudang Distributor

PT Satria Karya Adi Yudha Sidoarjo 
Berdasarkan hasil analisis yang dijelaskan oleh penulis maka agar gudang cabang PT Satria Karya Adi Yudha Sidoarjo dapat menciptakan kelancaran dalam proses pendistribusiannya dan juga agar dapat mengefisiensi ketersediaan barang dagang, maka penulis memberikan usulan sebagai berikut:

1. Perusahaan lebih meningkatkan fungsi persediaanya agar tidak lagi terdapat selisih barang pada saat proses pengiriman. Sehingga, perusahaan akan terus mendapatkan ketepatan jumlah barang dan ketepatan waktu dalam proses pengiriman. Dalam hal ini, perusahaan dapat memberi tugas tambahan kroscek kartu stok gudang dengan fisik, jika ditemukan selisih pada saat itu juga, dan jika di temukan barang yang secara fisik mengalami jumlah stok minimum, maka dapat langsung dibuatkan daftar order barang ke pusat. Sehingga, jika pada proses permintaan barang dari anak cabang perusahaan dapat mengantisipasi masalah tersebut.

2. Agar tidak terus menerus terdapat kelebihan dan selisih stock dalam penerimaan dan pengeluaran barang. Perusahaan seharusnya lebih tegas kepada bagian Gudang agar lebih bertanggungjawab lagi. Dalam hal kelebihan stok barang, bagian gudang dapat segera menginformasikan ke bagian admin agar melakukan pembatalan order item tersebut. Dan melakukan stock opname setiap satu bulan sekali.

3. Dalam kelancaran proses pendistribusian barang dagang akan lebih efektif dan efisien jika perusahaan menggunakan sistem informasi akuntansi yang memadai. Berikut ini penulis akan memberikan usulan dan penjelasan sistem informasi akuntansi pengiriman barang yang seharusnya dilaksanakan gudang cabang PT Satria Karya Adi Yudha Sidoarjo agar tidak terjadi permasalahanpermasalahan tersebut diatas (Lampiran 1).

\section{SIMPULAN}

Tidak adanya Prosedur dan Sistem Informasi Akuntansi pengeluran barang dalam gudang cabang PT. Satria Karya Adi Yudha Sidoarjo yang memadai,karena sering kali dalam proses barang siap dikirim ke anak cabang sering melakukan tambahan order yang dilakukan tanpa melalui prosedur, oleh karena itu gudang cabang PT.Satria Karya Adi Yudha sidoarjo sering kali mengalami keterlambatan dalam proses pengiriman barang dan menimbulkan selisih kartu stok persediaan barang, akan tetapi perusahaan masih tetap menjalankan pengiriman barang meskipun terjadi selisih kartu stok. sebab, tidak adanya tanggung jawab dari bagian gudang dalam perhitungan kartu stok dengan stok (fisik) akan berpengaruh pada kerugian anak cabang dalam meminimalisasi stok slow movingdan fast moving. Prosedur pengiriman barang pada gudang cabang PT. Satria Karya Adi Yudha Sidoarjo akan memadai, jika bagian gudang melakukan prosedur pengeluaran barang yang sesuai dengan sistem dan prosedur pengiriman barang gudang cabang PT Satria Karya Adi Yudha Sidoarjo yang dimulai dari bagian gudang kepada bagian pengiriman harus disetujui oleh bagian admin gudang cabang. Sehingga akan lebih baik lagi dalam tercapainya tujuan perusahaan. sehingga,Selisih stok yang selama ini terjadi dapat diminimalisasi dengan sistem informasi akuntansi pengeluaran barang dagang yang diusulkan oleh peneliti dan pengeluaran barang dibuatkan sistem secara komputerisasi yang tepat, agar perusahaan dapat lebih meningkatkan sistem informasi akuntansi persediaan barang dagang dalam kelancaran proses pendistribusian dan juga mendapatkan ketepatan waktu dalam 
proses pengiriman dan efisiensi terhadap persediaan barang dagang.sehingga, Perusahaan harus meningkatkan rasa tanggung jawab pada bagian gudang dengan memberikan data barang untuk digunakan sebagai acuan dalam menetukan stok minimum dan maksimum. Sehingga, gudang cabang dapat mengefisiensi jumlah ketersediaan barang dagangyang slow moving dan fast moving.

\section{DAFTAR PUSTAKA}

Anisa. ( 2015 ) . "Analisis Pengedalian Internal atas Persediaan Barag dagang pada PT.WAVIN TUNAS UTAMA ,Surabaya" (Universitas Bhayangkara Surabaya )

Boodnar, George.H danHopwood William S .2015.Sistem Informasi Akuntansi Yogyakarta

Hall James A .2007.Sistem Informasi Akuntansi, Edisi 4, Salemba Empat, Jakarta.

Ikatan Akuntan Indonesia.2014. Pengertian Persediaan dagang, Jakarta : Salemba Empat. Krismiaji .2015.Sistem Informasi Akuntansi, Edisi Kedua, Yogyakarta.

Mulyadi.2016.Sistem Akuntansi.Cetakan tiga dan Keempat, Salemba Empat, Jakarta. Rahmadiansyah.2013 , "Evaluasi Sistem Pengendalian Intrernal atas ersediaan barang pada PT. Indomarco Prismatama ( indomaret )", Universitas Bhayangkara, Surabaya

Rangkuti, Freddy.. Manajemen Persediaan, Aplikasi di Bidang Bisnis, Raja Grafindo Persada, jakarta.

Romney, B, Marshall, Steinbart Paul Jhon 2015, Accounting Information System,Edisi 9, Salemba Empat, jakarta.

Sujarweni ,V, Wiratna.2015 . Sistem Akuntansi ,Cetakan Pertama, pustaka baru Press, Yogyakarta.

Tiara ,2015.“Analisis Pengendalian Intern Terhadap Pengendalian Intern Terhadap Pengelolahan Persediaan Barang Dagangan Pada UD. Sari Bumi Bangunan Waru Sidoarjo "( Universitas Bhayangkara Surabaya ) 
Ekobis: Jurnal Ekonomi \& Bisnis

Vol. 1 No. 12020

Safitri Damayanti dkk., Efektivitas Manajemen Persediaan

Lampiran 1. Bagan Alir Sistem Informasi Akuntansi Penerimaan dan pengeluaran barang dari cabang ke customer ( usulan peneliti )
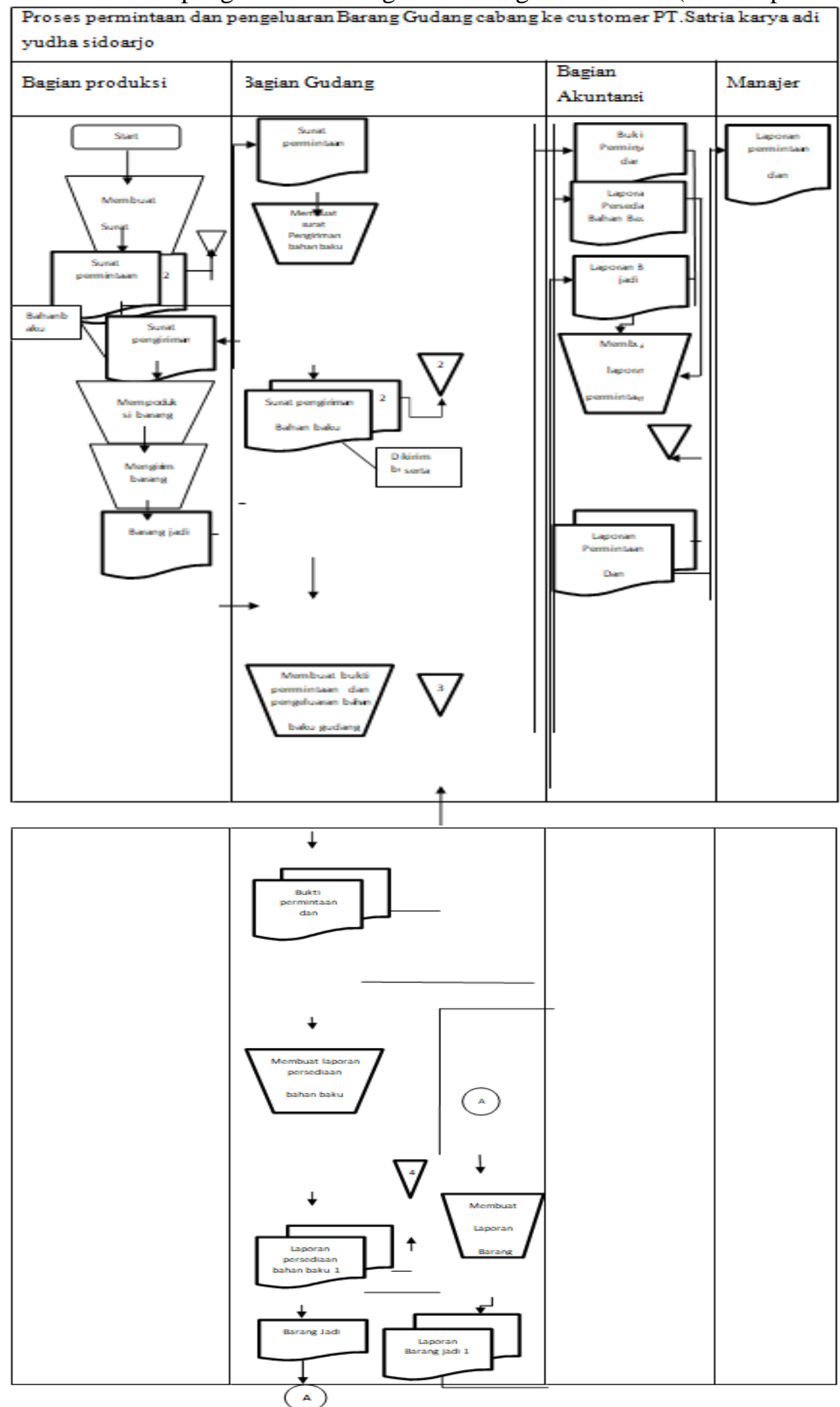